was peculiar puffy swelling of the hand, which did not pit on pressure and felt like an elastic cushion. The swelling increased and extended up the forearm to the middle of the arm. After a week it reached its height when a thrombus could be felt in the axillary vein. The superficial veins of the upper chest on the left side were enlarged and the lower part of the face was slightly swollen. A thrombus could be traced upwards in both the internal and external jugular veins for a distance of over two inches, while below was a hard tender cord which disappeared behind the clavicle. After about two weeks the swelling of the hand began to diminish. The tenderness and swelling at the root of the neck had almost disappeared when she was seized with pain on the right side of the neck where a red and tender swelling similar to that of the left side developed. The supraclavicular fossa was swollen and the superficial veins of the upper chest were enlarged. Three days later the right hand began to swell and soon it reached the size attained by the left. The forearm became affected and the axillary vein could be felt thrombosed. The thrombosis then extended to the basilic vein. The left hand remained swollen until death which took place four weeks after the onset of the thrombosis. Without warning the patient became unconscious, evidently from thrombosis of the sinuses of the brain. Examination showed extension upwards of the thrombus in the internal jugular vein with considerable cedema of the face and neck on that side. A necropsy was not allowed.

\section{INTERNATIONAL CONGRESS OF SCHOOL HYGIENE.}

THE first meeting of the International Congress of School Hygiene took place at Nuremberg on April 5th under the patronage of His Royal Highness Prince Ludwig Ferdinand of Bavaria. The direction of the Congress was in the hands of the chairman of the Allgemeiner Deutscher Verein für Schulgesundheitspflege, Professor Dr. H. Griesbach, with the support of the following foreign societies: Ligue des Médecins et des Familles pour l'Amélioration de l'Hygiène Physique et Intellectuelle dans les Ecoles, the Schweizerische Gesellschaft für Schulgesundheitspllege, the Allgemeen Prdologisch Gezelschap in Antwerpen, the Vereeniging tot Vereenvondiging van Examens en Onderwijs, and an English committee formed by representatives of the Royal College of Physicians of London, the Royal College of Surgeons of England, the Medical Officers of Schools Association, the London School Board, the Sanitary Institute, London, and the Incorporated Society of Medical Officers of Health, with Sir Lauder Brunton as President and Dr. James Kerr, the medical officer to the London School Board, as honorary secretary. The inaugural meeting of the Congress was held in the large hall of the Apollo Theatre on April 5th at 9 o'clock and was opened by His Royal Highness Prince Ludwig Ferdinand of Bavaria in person. The chair was taken by Professor Dr. Griesbach, of Mülhausen, who requested the Prince to open the Congress. The Prince said that it was with the greatest pleasure that he declared the first International Congress of School Hygiene open. He welcomed to Nuremberg the delegates from neighbouring States and distant lands. Professor Dr. Griesbach said that no less than 20 States were represented at the Congress and that Turkey and Italy alone were unrepresented. Delegates from the various countries then thanked the Prince and the committee for their welcome to the Congress. Dr. Eichholz, as representative of the University of Oxford, returned thanks on behalf of Great Britain.

THE London County Council has announced that chickenpox is to be a notifiable disease for a period of four months from April 8th. Every medical man in the administrative county of London has received a notice informing him that in case he should be in doubt as to whether a case under his care is or is not one of small-pox he can without fee obtain the opinion of either Mr. S. Bingham, formerly medical superintendent of one of the Metropolitan Asylums Board small-pox hospitals, or of Mr. W. McO. Wanklyn, late small-pox referee to the Metropolitan Asylums Board. Letters should be addressed: Medical Consultant, Public Health Department, 8, St. Martin's-place, Trafalgar-square, W.C. This arrangement will continue until August 7th.

Mr. F. W. Lowndes, the honorary secretary of the United Kingdom Police Surgeons' Association, has requested us to state that he will send a copy of the Statutory Declaration and Orders, 1903, to any member of the association or any medical practitioner on receipt of a letter addressed to him at 40 , Knight-street, Liverpool, with two penny stamps inclosed. This important official paper gives full details of the increased fees and allowances sanctioned by the Home Secretary to medical witnesses on the recommendation of the Departmental Committee, 1902.

Professor Seeley of King's College, London, proposes to conduct ten geological excursions which should be of interest to all London sanitarians. The object of the excursions will be to examine the main channel of the Thames and some of its tributaries. A beginning will be made on April 23rd at Purfleet where the Thames flows over the chalk.

THE members of the medical staff of the West London Hospital will hold a conversazione, in connexion with the Post-Graduate College, at the hospital on Wednesday, April 20th, at 8.30 P.M.

\section{WHO PERFORMED LITHOTOMY ON MR. SAMUEL PEPYS ? 1}

By D'Aroy Power, F.S.A., F.R.C.S. ENG,, TREASURER OF THE SAMUEL PEPYS CLUU.

WE celebrate to-night the two hundred and forty-sixth anniversary of one of the great events in the life of Samuel Pepys-the day when he was successfully cut for stone at. the house of Mrs. Turner in Salisbury-court, Fleet-street. The recollection of the day was often in his thoughts and the entry in his Diary on March 26th, 1660, is a faithful reflection of his usual state of mind at each return of spring. It runs: "This day it is two years since it pleased God that I was cut of the stone at Mrs. Turner's in Salisbury Court. And did resolve while I live to keep it a festival, as I did the last year at my house, and for ever to have Mrs. Turner and her company with me." Two years later, on March 26th, 1662, the entry is: "Up early. This being by God's great blessing the fourth solemn day of my cutting for the stone this day four years, and am by God's mercy in very good health. ...... At noon came my good guests, Madame Turner, ${ }^{2}$ The., ${ }^{3}$ and Cozen Norton and a gentleman, one Mr. Lewin of the King's Life-Guard. ...... I had a pretty dinner for them-viz., a brace of stewed carps, six roasted chickens and a jowl of salmon hot for the first course : a tanzy and two neats' tongues and cheese the second : and were very merry all the afternoon talking and singing and piping upon the flageolette. ...... We had a man cook to dress the dinner to.day and sent for Jane to help us." This is but a single example of many such pleasant dinners and in continuation of them we have met here tonight.

But the club is founded to elucidate as well as to celebrate events in the life of Mr. Pepys and I propose to ask to-night who operated upon Mr. Pepys? I do not think

1 A paper read at the second meeting of the Samuel Pepys Club on March 26th, 1904.

2 Daughter of John Pepys of South Creake and wife of Serjeant John, Turner, Reader in Law. 
that he anywhere mentions the name of the surgeon, but he was on terms of intimacy with two surgeons, Mr. James Pierce and Mr. Thomas Hollier. James Pierce seems to have been under the protection of Lord Sandwich and it was in this manner no doubt that Pepys became acquainted with him. After the Restoration he was appointed surgeon to the Duke of York, Surgeon-General of the Fleet, and Groom of the Privy Ohamber to the Queen. He hoped to be appointed surgeon to St. Thomas's Hospital by the influence of the Duke of 'York when Tom Woodall was killed in a drunken quarrel in 1666, but I do not find that he was ever elected to the office and he must not be mistaken for Mr. William Pearce who was some time a colleague of $\mathbf{M r}$. Hollier at St. Thomas's Hospital. James Pierce was master of the Barber-Surgeons' Company in 1675 and was at that time surgeon to the King. Although Pierce was well known to Mr. Pepys he does not seem to have consulted him professionally on any occasion and I think we may say with certainty that Pierce was not his lithotomist.

Thomas Hollier was a man of different calibre. He was appointed surgeon "for scald heads" at St. Thomas's Hospital in 1638 and on Jan. 25th, 1643 44 he was chosen surgeon to the hospital in place of Edward Molines, surgeon for the cutting of the stone to the hospital, who had left his place to join the King's army at the beginning of the war. Molines was taken in arms against the Parliament at Arundel Castle and was in consequence deprived of his office as surgeon to St. Thomas's Hospital on the day when Hollier was appointed. After the Restoration King Charles ordered the governors to reinstate Molines; but as the place had already been well filled by Hollier the governors were unwilling to displace him. There was a considerable correspondence and the difficulty was solved at last by the appointment of Molines as a fourth or additional surgeon, the stipend of the surgeons being reduced from $£ 40$ to $£ 30$ apiece.

Mr. Hollier acted as a second warden of the BarberSurgeons' Company in 1665, when Mr. Serjeant-Surgeon Wiseman was master, and was himself master of the Company in 1673. In 1669 the College of Physicians bought his house and grounds, extending from Warwick lane to the City walls. for $£ 1200$ to build a new college in place of the college in Amen-corner which had been destroyed by the Great Fire. Hollier's position as lithotomist gave him unusual opportunities to perfect his skill and he is said to have cut no less than 30 persons for stone in one year without a single death, a result of which he might be justly proud were he living amongst as now. Hollier seems to have been the trusted medical adviser of Mr. Pepys, for he bled him, gave him sound advice on many occasions, and when Mrs. Pepys was ill he was summoned to attend her, and though a surgeon he refrained from operating. Sir Frederick Bridge, in his recently published book "Samuel Pepys, Lover of Musique" (p. 63), draws attention to certain entries in a volume of the Sloane MSS. at the British Museum. ${ }^{4}$ These entries consist of two prescriptions written by $\mathrm{Dr}$. J. M., the second being countersigned by Dr. G. Jolly. The first prescription is headed "Before he was cut for the stone by Mr. Hollier" and is ordered "for Mr. Peapes." It is a soothing draught, such as might still be given with advantage to a patient whose bladder was inflamed. It contains liquorice, marsh mallow, cinnamon, milk, rose water, and the whites of eggs carefully distilled over a slow fire. The dose ordered was six ounces with an ounce of syrup of althea, ${ }^{5}$ to be taken daily in the morning and at bedtime. On the next page of the Sloane MS. is a second prescription for a draught to be in readiness when he was cut. "For Mr. Peapes who was cut for ye stone by Mr. Hollier, March ye 28th (1658) and had a very great stone taken that day from him." This prescription again is for a cooling and demulcent drink such as we still give to a patient whose mouth is parched after an operation. Its chief constituent was lemon juice to which a little syrup of radishes was added. It shows that $\mathrm{Mr}$ Pepys was expected to be feverish after the operation, but

\section{Sloane MSS., No. 1536, f. 63, margin.}

5 The syrup of althea itself was: $R$ Roots of Althea two ounces roots of grass, asparagus, Liquorice cleansed: Raisons stoned : ana half an ounce. Taps of marsh mallow : leaves of mallow, Pellitory : Burnet : Saxifrage : Plaintain : White and Black Maidenhair: ana M. (a handful) $i$ : Red Cicers an ounce : of the four greater and lesser cold seeds ana three ounces. Infuse them a whole day in clear water, lb. vi Boil to the consumption of two pounds : then strain and press and with sugar, lbs. jiiss. make a syrup in Balneo Mariae according to Art. the surgeons did not think he would be collapsed or dangerously ill, for the prescription especially mentions that musk was not to be employed and we know that musk in those days was held to be as sovereign a remedy for collapse as is alcohol now. Indeed, few people died in a regular way until they had received a viaticum of musk. It is curious that the prescription should be dated March 28th when Pepys says repeatedly that he was operated upon on March 26th, but we all know that there are other and similar discrepancies of date in the Diary which can in no way be reconciled.

I can find nothing about Dr. Jolly, who signs the prescription, except the reference to him under date, Feb. 27th and $28 \mathrm{th}$, 1662, where Pepys says about a demonstration of anatomy at the Hall of the Barber-Surgeons : "Dr. Scarborough upon my desire and the company's did show very clearly the manner of the disease of the stone and the cutting and all other questions that $I$ could think of ....... how the water comes into the bladder through the three skins or coats just as poor Dr. Jolly has heretofore told me." It appears from this passage that Dr. Jolly had died between the time Pepys was cut and the date of his beginning the Diary in January, 1659-60. There is no mention of Dr. Jolly in the Roll of the College of Physicians, nor was he a graduate of the University of Oxford.

The initials Dr. J. M. at the foot of each prescription stand, I have very little doubt, for Dr. James Moleyns, the leading lithotomist of his time, father of Edward Molines referred to above, and in all probability the master and teacher of Thomas Hollier. I feel a personal interest in James Moleyns because he was a predecessor in the great hospital of St. Bartholomew which I have the honour to serve. He held the office of "surgeon for the stone" both at St. Bartholomew's and at St. Thomas's Hospitals. At a time when medicine and surgery were absolutely divorced and surgery held a very inferior position James Moleyns was one of the very few people licensed by the College of Physicians to administer internal medicines in surgical diseases. His licence is dated Sept. 24th, 1627. $\mathrm{He}$ died in 1686 and is buried in St. Bride's, Fleet-street.

We have some interesting information in the books at St. Bartholomew's Hospital about Dr. James Moleyns or Mullins. He succeeded Mr. Robert Murrey, surgeon to the Lock Hospital, in 1622 and after a conference between the governors of St Bartholomew's and those of St. Thomas's Hospitals duties were assigned to him in the following order :-

Vicesimo die Januarii Anno. Dni. 1622-3.

It is ordered by the Governors of this Hospitall that James Mullins Chirurgion in consideracon of his care and paynes which he is to take in cuttinge and cureinge of poor diseased p'sons of the Stone, and the greifs and Malladies hereunder named, brought to the sev'all hospitalls of St. Barth'ewes and St. Thomas in Sow thwarke, shall have the yearly stipend of $\times x \times l i$. per anm. from XXmas last past soe longe as he shail discharge the same cures to the good likeinge of the Governors of the said hospitalls viz. xvl. of his said stipend to be paid him quarterly from this hospitall and the other xvl. from St. Thomas' Hospll. and be is alsoe to be allowed two pounds of towe for every patient for theire more easie and warmer dressinge.

For the annuall stipend of thirty pounds I under take (wth. God his helpe) my best skill and experience the manuall operacon and chirurgicall cuer of these issuinge Maladies viz.

The Cureinge by insition the stone in the yard or Bladder.

The cureinge of the rupture or falling downe of the Intestines or gutts into the Codds by Cuttinge.

The Cureinge by Insition the Carnosity or fleshie substance in the Codds.

Also the Curinge of Wenns by Insition.

Desiringe that for every patient I may have the allowance of 2 pounds of towe for theire easier and warmer dressinge.

It will appear from these statements that the governors of the two hospitals appointed a special surgeon for the treatment of those conditions which had so far fallen into the hands of quacks (lithotomists, hernia specialists, and fistula curers) that the ordinary surgeons left them untended. It was no doubt due to these wise orders and to the appointment of suitable persons at the hospitals that lithotomy and hernia once more came to be considered a part of legitimate surgery. Now $I$ think it is clear from the facts I have brought together that Mr. Pepys was operated upon by Mr. Hollier who had called into consultation his old master, Dr. James Mullins. He thus came under the care of the two best lithotomists of the time and I suspect that they used more than two pounds of tow for his dressings. If $\mathrm{Mr}$. Hollier was his lithotomist there is a good reason why he should have taken rooms at Mrs. Turner's in Salisbury.court, for he would wish to be as near as possible to his surgeon who was living in Warwick-lane. 